DARIUSZ BRZOSTEK

Uniwersytet Mikołaja Kopernika w Toruniu

\title{
SHERLOCK HOLMES, MAGLOWNICA I BEZSENSOWNY RYTUAL. DEMONICZNOŚĆ (I) POWTÓRZENIA W POPKULTURZE
}

W roku 1979, w swoim szkicu The Meaningless of Ritual, niegdyś kontrowersyjnym, dziś już w zasadzie klasycznym, Frits Staal analizując złożony wedyjski rytuał agnićajana ${ }^{1}$, postawił tezę, że praktyka rytualna sprowadza się do czystego działania, nie generując sensów ani znaczeń i reprodukując tylko (lub aż) mniej lub bardziej skomplikowaną składnię obrzędu. Jak zauważa Staal: „Rytuał jest więc przede wszystkim działaniem. Działaniem podporządkowanym zewnętrznym regułom. Najważniejsze jest w nim to, co robisz, a nie to, co myślisz, mówisz lub w co wierzysz" (Staal 1979: 4). Ortopraksja zajmuje w nim uprzywilejowane miejsce ortodoksji, zaś jego funkcja okazuje się nadzwyczaj prosta, gdyż: „Jedynymi wartościami kulturowymi, jakie przekazują rytuały są same rytuały" (Staal 1979: 8). Obserwacje te wiodą Staala wprost do (nie)oczekiwanej konkluzji, stwierdzającej, że „rytuał nie posiada znaczenia, przeznaczenia ani celu" (Staal 1979: 8). Reprodukuje się jako kulturowa praktyka w sposób doskonale bezsensowny (meaningless), narzucając zarazem, w czasie swego trwania, określony porządek oraz strukturyzując działania, akty i wypowiedzi w taki sam sposób, w jaki czyni to składnia języka w mowie. Podstawowe cechy rytuału to zatem: ortopraksja, bezsensowność i wreszcie, wynikająca $\mathrm{z}$ nich, łatwość powtarzania i odtwarzania praktyki rytualnej. W tym sensie pozbawiona znaczeń - lecz nie kulturotwórczej funkcji - reprodukcja rytuału okazuje się w istocie doskonałym modelem reprodukcji kulturowej, w której formy są trwalsze od sensów, a powtarzalność praktyki jest warunkiem skuteczności wytwarzania habitusów (Bourdieu 2007: 192-214).

Zastanawiające może jednak być to, że podobne opisy zachowań zrytualizowanych, bądź rytuałów par excellence odnajdziemy bez większego trudu w popularnych opowieściach kryminalnych i historiach z dreszczykiem. W znanej noweli Arthura Conan Doyle'a, Rytuat Musgrave'ów, Sherlock Holmes staje w obliczu zagadki niewyjaśnionego zaginięcia, związanego $\mathrm{z}$ enigmatycznym, pozornie bezsensownym rytuałem dotyczącym historii rodowej posiadłości. Obrzęd ów sprowadza się do powtórzenia kilku prostych formuł i gestów, które jeden z bohaterów tak relacjonuje detektywowi:

- Podał mi papier, który tu widzisz. Jest to rodzaj katechizmu, zbiór podstawowych zasad, których każdy Musgrave musi się nauczyć, gdy dojdzie do pełnoletności. Przeczytam ci kolejno pytania i odpowiedzi:

- Czyje to było?

- Tego, kto odszedł.

- Czyje to będzie?

- Tego, kto przyjdzie po nim.

- W jakim to było miesiącu?

- W szóstym od pierwszego.

${ }^{1}$ Agnićajana to ,spektakularna ceremonia, podczas której główny ołtarz ogniowy, identyfikowany $\mathrm{z}$ ciałem ofiarnika, powinno się wznosić w kształcie ptaka z rozłożonymi do lotu skrzydłami (skr. śyena). Był to wielki, złożony rytuał ogniowy, należący do ceremonii somowych, trwający wiele dni i nocy (dwanaście dni rytualnych). Jednym $z$ jego bloków składowych, ustawionym jako kulminacyjna sekwencja, było ofiarowanie somy (rośliny, z której wytwarzano trunek wprowadzający w stan ekstatyczny)”. (Nowicka 2015: 36). 
- Gdzie stało słońce?

- Nad dębem.

- Gdzie był cień?

- Pod wiązem.

- Jak wymierzyć krokami?

- Na północ dziesięć i dziesięć, na wschód pięć i pięć, na południe dwa i dwa, na zachód jeden i jeden, i w dół

- Co za to winniśmy dać?

- Wszystko, co mamy.

- A dlaczego musimy to oddać?

- Bo nam to powierzono.

Oryginał nie ma daty, ale z pisowni wynika, że dokument pochodzi z połowy XVII wieku zauważył Musgrave. - Doprawdy, obawiam się, że ten papier niewiele panu pomoże w rozwikłaniu tajemnicy (Conan Doyle 2007: 15-16).

Jak nietrudno zauważyć, jest to dość prosty zapis lub rekonstrukcja pewnego działania „podporządkowanego zewnętrznym regułom” wyrażonym wprost w cytowanych powyżej formułach językowych określających zarówno kategorie czasowe (,szósty miesiąc”), przestrzenne („,dziesięć i dziesięć kroków na północ”), jak i powinności wykonawcy („,oddać wszystko, co mamy”), co sugeruje zrytualizowany, a nawet ofiarniczy charakter tego gestu. Sam akt, nawet - a może zwłaszcza - w oczach wykonawców, wygląda na działanie zupełnie nonsensowne i niepraktyczne, o czym skrupulatnie informuje nas narrator opowieści:

Lampka wciąż jeszcze stała na biurku i w jej świetle ujrzałem, jaki dokument wyjął z sekretery. Ze zdziwieniem stwierdziłem, że nie było to nic ważnego. Po prostu kopia pytań i odpowiedzi wymienianych podczas pradawnego, niezwykłego obrządku nazwanego rytuałem rodu Musgrave'ów. Jest to, tradycyjna już, nasza rodzinna ceremonia, przez którą od wieków musi przejść każdy z Musgrave'ów, gdy dojdzie do pełnoletności. Sprawa czysto prywatna, która może zainteresować historyka, tak jak nasze herby i dewizy rodowe, a poza tym jest bez znaczenia (Conan Doyle 2007: 12).

Rzecz jasna sam Holmes jest odmiennego zdania i dostrzega w tekście także porządek semantyczny, swoistą zakodowaną wiadomość przekazywaną przez wieki w rodzinie Musgrave'ów. Jej poprawne odczytanie jest zarazem kluczem do zagadki kryminalnej i sekretnej historii sprzed stuleci, o czym detektyw informuje świadków w finale opowieści: „Byłem przekonany, że wszystkie trzy tajemnice to w gruncie rzeczy jedna i, jeżeli zdołam rozwiązać zagadkę rytuału, odnajdę klucz do tajemnicy zaginięcia kamerdynera Bruntona i pokojówki Howells" (Conan Doyle 2007: 17). Dalsza interpretacja owych pozornie bezsensownych gestów i wypowiedzi pozwala Holmesowi rozwikłać kryminalną historię, w której dzieje powierzonego skarbu (korona królów Anglii) splatają się z próbą jego odnalezienia i przywłaszczenia. Rytuał nie okazuje się zatem strukturą „,pozbawioną znaczenia” (czystą składnią), lecz raczej taką, która owo znaczenie utraciła w ciągu stuleci. Najistotniejszy jest tu jednak fakt, że nawet w takiej formie zdołała przetrwać i funkcjonować skutecznie w rodzie Musgrave’ów, zyskując zupełnie nową - czysto inicjacyjną funkcję (,aktu wprowadzającego w pełnoletność"). Sensowność nie jest zatem niezbędnym aspektem skutecznego działania rytualnego.

Popularna nowela Stephena Kinga Magiel - zekranizowana w roku 1995 przez Tobe'a Hoopera - opowiada z kolei groteskową historię demonicznego opętania starej maglownicy w miejskiej pralni przez złośliwego demona, łącząc technikę z demonologią, współczesną cywilizację $\mathrm{z}$ antycznymi wierzeniami oraz zmechanizowany proces maglowania bielizny z rytualną mechaniką przywoływania demonów. Istotą tej noweli, a mówiąc dokładniej, konstytuującego jej kompozycję schematu fabularnego, nie jest 
jednak opowieść o demonicznej inwokacji dokonanej przez grupę wyznawców w celu przywołania pradawnego bóstwa, jak to ma miejsce w klasycznych opowiadaniach H.P. Lovecrafta np. Zew Cthulhu (Lovecraft 2012), lecz historia przypadkowego, nieświadomego - w istocie zaś czysto mechanicznego przywołania demona w wyniku zaskakującego, lecz nie niemożliwego, zbiegu okoliczności.

- Spytałem cię kiedyś, czy bierzesz pod uwagę to, że magiel może być nawiedzony - odezwał się Jackson, kiedy policjant skończył. - Nie do końca wtedy żartowałem. Teraz pytam ponownie. [...] „Nawiedzony” to złe słowo. Powiedzmy: „opętany”. Istnieje tyle samo zaklęć przywołujących demony, co je odpędzających. W książce Frazera Złota gałą́ znajdziesz ich całe mnóstwo (King 2007: 128-129)

Jak to w ogóle możliwe? Skąd antyczny demon w maszynie? Co go sprowadziło w sposób tak skuteczny?

Większość anglosaskich formuł magicznych wymienia ziemię cmentarna albo oko ropuchy. Europejskie źródła wspominają często o ręce chwały, którą należy tłumaczyć albo w sensie dosłownym, czyli jako rękę trupa, albo alegorycznie, jako któryś z halucynogenów ściśle powiązanych z sabatami czarownic, zazwyczaj belladonę lub wyciąg z meksykańskich grzybów z gatunku Psilocybe. Ale mogą być i inne (King 2007: 129-130).

Jeśli zatem określony zestaw elementów (krew dziewicy, substancja halucynogenna etc.) znajdzie się, nawet zupełnie przypadkowo, w jednym miejscu i zostanie w nim połączony (tu: zmielony przez magiel), proces inwokacji zostanie uruchomiony w sposób automatyczny, a więc bez woli, wiedzy, intencji, a nawet udziału uczestników. Obrzęd przywołania będzie dokonywał się mechanicznie, jako określone następstwo gestów podporządkowanych ,zewnętrznym regułom”. „Jeśli siedemset małp przez siedemset lat będzie pisać na maszynie... jedna $\mathrm{z}$ nich napisze w końcu dzieła Szekspira" (King 2007: 130) konstatują ostatecznie bohaterowie w obliczu „niemożliwego”, które ujawnia się nagle w starej maszynie. Co więcej, odczytanie odpowiedniego porządku „rytualnego” (zestawu elementów oraz ich następstwa) pozwala nawet dokonać identyfikacji istoty demonicznej ${ }^{2}$ i wpisać ją w obszerniejszy system klasyfikacji oraz praktyk magicznych pozwalających odesłać demona w zaświaty:

- W porządku - powiedział Jackson. - Zatrudniłem komputerowca... myślał, że przygotowuję jaką́s hecę na Halloween... Przeprowadził pozytywną analizę wszystkich podstawowych i drugorzędnych pozycji z tej listy. Sprawdził każdą możliwą kombinację. Jakieś dwa tuziny wyrzuciłem, bo nie miały najmniejszego sensu. Te, które zostały, dają się ująć w całkiem wyraźne kategorie. W jednej z nich występują wszystkie wydzielone przez nas elementy.

- W której?

Jackson wyszczerzył zęby.

- W najprostszej. W mitologii południowoamerykańskiej, żywej również na Karaibach. Jest związana z kultem wudu (King 2007: 136).

Podobne przykłady można by bez trudu mnożyć, warto jednak przywołać w tym kontekście jeszcze tylko jeden, w sposób dość spektakularny ilustrujący mechaniczny charakter rytuału. Oto bowiem w znanym opowiadaniu Clive'a Barkera Powrót z piekła, które stało się osnową cyklu filmów grozy Hellraiser, kluczem do bram piekielnych

${ }^{2}$ Należy tu oczywiście pamiętać i o tym, że popularne reprezentacje (literackie lub filmowe) istot demonicznych, jakkolwiek odwołują się często do tekstów folkloru i wierzeń tradycyjnych, funkcjonują w opowieściach grozy jako swoiste ,znaki puste” - nie przywołując całego systemu mitologicznego i nie zakładając bynajmniej mitycznego stylu odbioru. Kwestię te omawia obszernie Violetta Wróblewska (Wróblewska 2014). 
a zarazem obrzędem demonicznej inwokacji jest nie zestaw formuł magicznych, lecz zabytkowa pozytywka („kostka Lemarchanda”) - jej, intencjonalne lub nieświadome, uruchomienie inicjuje proces rytualny skutkujący przywołaniem demona:

- To się nazywa Konfiguracja Lemarchanda - powiedziała postać, wskazując na kostkę.

Kirsty spojrzała. Kawałki kostki nie leżały już na jej dłoni, ale unosiły się kilkanaście centymetrów ponad nią. W cudowny sposób kostka składała się sama, bez niczyjej pomocy. Kawałki wsuwały się na swoje miejsce po kolei i wreszcie cała konstrukcja znów była całością (Barker 1992: 126).

Tu także przebieg rytuału sprowadzony jest do zestawu sformalizowanych, pozbawionych znaczenia gestów, których wykonanie okazuje się skuteczne. Wykonawca nie tylko nie musi rozumieć sensu swego działania, ale nawet nie musi wiedzieć, co w istocie robi. W tym kontekście przywołane powyżej przykłady doskonale obrazują sytuację, w której rytuał okazuje się po prostu swoistą „gramatyką praktyki”, czyli (zewnętrzną choć zinternalizowaną i ucieleśnioną) „regułą” pojmowaną zarazem jako „zasada objaśniająca działanie i kierująca nim norma” (Bourdieu 2007: 230). Wszystko to wiedzie nas do, wynikającej wprost z konstatacji Staala, ale bliskiej także rozpoznaniu Pierre'a Bourdieu, konkluzji, że uczestnicy rytuału nie wiedzą (nie muszą wiedzieć), co robią, dlaczego to robią, ale $\mathrm{z}$ całą pewnością wiedzą (muszą wiedzieć), jak to robić wiedza ta rodzi się natomiast wprost $\mathrm{z}$ powtórzenia określonej praktyki (rytualnej). $\mathrm{W}$ tym miejscu należy oczywiście postawić pytanie o to, co wynika $\mathrm{z}$ takiej konstatacji wywiedzionej z analizy kilku (nawet wielu) popularnych opowieści, które nie są wszak $\mathrm{z}$ pewnością literaturą antropologiczną, nawet jeśli w pewnym stopniu pozostają fikcjami antropologicznymi ${ }^{3}$. Aby wyjaśnić tę kwestię, powinniśmy przypomnieć, że literatura popularna $\mathrm{W}$ całości ufundowana jest na elementarnej zasadzie powtórzenia i że powtórzenie to dotyczy aktu reprodukcji konwencjonalnego schematu.

Pojęcie schematu (formula) wprowadził na szerszą skalę do badań nad literaturą popularną John G. Cawelti - określając ją zarazem mianem „literatury o najwyższym stopniu konwencjonalizacji" (Cawelti 1973: 48). Jego zdaniem schemat jest „konwencjonalnym systemem tworzenia produktu kulturowego” (Cawelti 1973: 48), który „ujawnia sposób, w jaki kultura wciela zarówno mityczne archetypy, jak i własne, współczesne elementy w formę narracyjną" (Cawelti 1973: 49). Schemat jest więc niejako wpisanym w tekst dowodem funkcjonowania pewnej konwencji w określonym polu literackim. Schematy, pozostając w ścisłych związkach ze szczególną formą kultury i określonym odcinkiem czasu historycznego - wyznaczają zespół norm, których literacka realizacja stanowi o swoistości utworu i jego przynależności do danej odmiany literatury popularnej. Klasyczne rozpoznania gatunków i konwencji literatury popularnej, dokonane na podstawie analizy jej schematów fabularnych i/lub tematycznych, przynosiły klasyczne już dziś prace narratologiczne Stanko Lasicia (Lasić 1976), Umberto Eco (Eco 1996) oraz Antoniego Smuszkiewicza (Smuszkiewicz 1980), ilustrując W sposób spektakularny poznawczą wydajność takiego podejścia metodologicznego oraz, co szczególnie istotne, dowodząc faktycznej obecności określonych modeli narracyjnych w popularnych opowieściach przygodowych (a zatem skoncentrowanych kompozycyjnie wokół akcji - działania).

To oczywiście nie wyjaśnia jeszcze przeprowadzonego w tym miejscu zestawienia popularnych narracji tematyzujących w obrębie fabuły właśnie ów element

${ }^{3} \mathrm{O}$ literaturze grozy jako fikcji antropologicznej, czyli opowieści reprodukującej kulturowe schematy poznawcze oraz towarzyszące im interpretacje etyczne i polityczne pisałem obszernie w książce Literatura i nierozum. Antropologia fantastyki grozy, (Brzostek 2009), podobne ustalenia w odniesieniu do literatury kryminalnej sformułowałem także w innych szkicach (Brzostek 2005; Brzostek 2013). 
kulturowej reprodukcji ufundowanej na „bezsensownej” powtarzalności praktyki. Aby go w pełni uzasadnić, należy wprowadzić jeszcze jeden aspekt - wyprowadzoną z teorii Freudowskiej koncepcję „niesamowitego”, w której kluczową rolę odgrywa właśnie problem nieświadomego powtórzenia oraz przymusu powtarzania. Przypomnijmy w największym uproszczeniu, że Freudowskie „niesamowite” (das Unheimliche) należy „do dziedziny tego, co przeraźliwe, wywołujące lęk i grozę” (Freud 1997: 235), związanej z tym, w czym, rzekomo, „nie mamy rozeznania” (Freud 1997: 236), zarazem jednak odsyłając nas do sfery tego, co ,»samowite« [heimlich], »swojskie« [heimisch], »znajome« [vertraut]" (Freud 1997: 236), lecz ,zakryte, trzymane w ukryciu” (Freud 1997: 239). Warto także pamiętać, że u podstaw poczucia „niesamowitego" w doświadczeniu Freud odkrywa właśnie ów osobliwy fenomen powtórzenia (a także „przymusu powtarzania”), którego istotę opisuje następującymi słowami: „to właśnie tylko czynnik niezamierzonego powtórzenia sprawia, iż coś skądinąd niewinnego staje się niesamowite i nieodparcie przywodzi nam na myśl ideę czegoś fatalnego, przed czym nie sposób uciec, choć w innej sytuacji w tych samych okolicznościach mówilibyśmy li tylko o »przypadku«” (Freud 1997: 249). Także „przykłady z życia”, po które sięga Freud, by zilustrować „niesamowity” aspekt powtórzeń są znamienne: błąkanie się w lesie i wracanie „na to samo miejsce charakteryzujące się specyficznym układem drzew” czy błądzenie w ciemnym pokoju, „by po raz nie wiadomo który zderzyć się z tym samym meblem" (Freud 1997: 249). Dowodzą one, iż zdaniem twórcy psychoanalizy „niesamowitość” kryje się w zdarzeniach codziennych i banalnych, uwolniona mocą niezamierzonego powtórzenia lub ,powracania spraw podobnych” (Freud 1997: 250). Rozwinięcie tych spostrzeżeń pojawia się w psychoanalitycznej koncepcji nerwicy natręctw, eksponującej kompulsywny charakter powtórzenia, gdzie Freud określa ów „przymus powtarzania” (Wiederholungszwang) jako „siłę przyciągania, jaką nieświadome wzory wywierają na wyparty proces popędowy" (Freud 2001: 261). W ujęciu Freudowskim fenomen ów wiąże się z „infantylnym życiem psychicznym” i jego psychopatologicznymi symptomami, takimi jak właśnie „natręctwo powtarzania”, wynikające ,z impulsów popędowych, które prawdopodobnie zależy od najbardziej wewnętrznej natury samych popędów i jest wystarczająco silne, by wysforować się przed zasadę rozkoszy, które pewnym aspektom życia psychicznego nadaje demoniczny charakter" (Freud 1997: 250).

Warto w tym miejscu podkreślić raz jeszcze, że „niesamowity” charakter doświadczenia nie implikuje w sposób konieczny fantastycznej istoty samego zjawiska, którym może stać się choćby nieoczekiwana koincydencja zdarzeń, taka jak w pamiętnej scenie z Czarodziejskiej góry Tomasza Manna, w której Hans Castorp spotyka starszą panią „o wyglądzie ponurym, a nawet tragicznym”, przemierzającą ogrodowe ścieżki wdziwnym rytmie: „widok tej czarnej i bladej kobiety, która zapewne bezwiednie stawiała swe długie, stroskane kroki w takt dolatującego marsza, był zaiste niesamowity" (Mann 1972: 63). W taki właśnie sposób - jako „niesamowity” (unheimlich; Mann 1974: 58) określa narrator powieści ów fenomen niezamierzonego, a więc nieświadomego, powtarzania przez staruszkę rytmu marsza dobiegającego $\mathrm{z}$ oddali. Tak oto banalna z pozoru sytuacja nabiera w oczach Hansa Castorpa niezwykłego i niepokojącego charakteru, łącząc w sobie zarazem element powtórzenia ${ }^{4}$ oraz aspekt nieświadomego działania.

\footnotetext{
${ }^{4}$ Gwoli ścisłości - powtórzenie polega tu na obserwowanym przez Castorpa fakcie, że staruszka nieświadomie powtarza w swych krokach rytm dobiegającej z oddali marszowej muzyki.
} 
Warto jednak podkreślić w tym miejscu właśnie ten, odnotowany już przez Freuda, demoniczny charakter przymusowego powtarzania, znajdzie on bowiem swe rozwinięcie w późniejszych koncepcjach nawiązujących do teorii psychoanalitycznej. Demoniczny aspekt powtórzenia odsłonił przed laty Harold Bloom w swej pracy Lęk przed wpływem, relacjonując zmagania angielskich poetów ze zniewalającym geniuszem Williama Szekspira. Istotą koncepcji Blooma jest ujęcie procesu historycznoliterackiego jako niekończącego się nigdy „wpływu poetyckiego, czyli historii relacji wewnątrzpoetyckich”, w wyniku których ,jeden poeta pomaga się ukształtować drugiemu" (Bloom 2002: 49). Wpływ ten jest nieuchronny, a sam proces ma także niebagatelną cenę - „wiąże się z przejmującym lękiem przed zadłużeniem - który bowiem z silnych twórców chciałby się dowiedzieć, że poniósł klęskę próbując stworzyć samego siebie?" (Bloom 2002: 49). Mamy tu zatem swego rodzaju lęk podmiotu twórczego przed zatraceniem się właśnie w powtórzeniach artystycznego gestu (stylu, kompozycji, motywów) mistrza. Proces ten ma zresztą, w ujęciu Bloomowskim, swój charakterystyczny przebieg, obejmujący sześć kolejnych etapów, z których najistotniejsze w przywołanym tu kontekście wydają się dwa: etap trzeci, Kenosis - „czyli mechanizm zerwania podobny do mechanizmów obronnych, jakich używa nasza psychika w walce $\mathrm{z}$ przymusem powtarzania" oraz etap czwarty, Demonizacja, gdy „poeta otwiera się na moc, którą zaczyna oddzielać od osoby rodzica i postrzegać jako należącą do sfery istniejącej poza prekursorem" (Bloom 2002: 57-59). Tym samym także sam proces twórczy zyskuje ów „niesamowity” aspekt, wynikający z nieświadomego i natrętnego powtarzania oraz towarzyszącego mu lęku.

Możemy teraz sformułować kilka uwag związanych z fenomenem powtórzenia „bezsensownego schematu” (the meaningless formula), by skontaminować $\mathrm{w}$ tym miejscu pojęcia zaproponowane przez Staala i Caweltiego, w kulturze popularnej, uwzględniając zarazem jego „niesamowity” (unheimlich) charakter i demoniczny potencjał, związany nie tylko z procesem kulturowej reprodukcji, ale także z tendencja do unikania wpływu (schematu) oraz próby uwolnienia się od społecznego przymusu powtarzania ustabilizowanych kulturowo formuł - sankcjonowanego w tym kontekście oczywiście nie przez wyparte treści psychiczne lecz przez motywacje ekonomiczne czy technologiczne - gra nie toczy się tu bowiem między „silnym poetą” i jego mistrzem, ani nawet między podmiotem twórczym i jego „nieświadomym”, lecz między (wy)twórcą produktu kulturowego i systemem, którego podstawy i założenia funkcjonowania mogą być tyleż oczywiste (zysk i dominacja symboliczna) co niejawne (strategie marketingowe, tajniki technologii produkcji).

Pozwolę sobie zatem sformułować w tym miejscu trzy tezy odnoszące się do przedstawionej powyżej problematyki. Teza pierwsza podąża wprost tropem myślenia Fritsa Staala i brzmi następująco: teksty popkultury przekazują prosty schemat reprodukcji tekstów popkulturowych, którego istotą jest, ni mniej ni więcej, tylko sama reprodukcja - wolna od semantyki, od owego bagażu znaczeń - symbolicznych, alegorycznych, mitologicznych czy ideologicznych - których pojemnymi nośnikami mogą jednak stać się bez trudu same teksty zależnie od kontekstu historycznego (oraz określonych czynników politycznych, społecznych czy ekonomicznych). W tym ujęciu należałoby jeszcze podkreślić, że reprodukcji podlegać mogą także konkretne schematy zakodowane $\mathrm{w}$ tekstach popkulturowych realizujących pewne formy konwencjonalne: złożona struktura odkrywania w horrorze (Carroll 2004: 170) czy narracja linearnopowrotna w powieści detektywistycznej (Lasić 1976: 61). Kluczowa jest tu jednak bez wątpienia zdolność odtwarzania owych schematów w opowieściach przyjmujących formę skonwencjonalizowanych tekstów (literackich, filmowych, gier etc.). Teza druga 
odnosi się wprost do przykładów przywołanych w tym szkicu. Oto bowiem niektóre teksty popkultury - takie jak nowele i opowiadania omówione powyżej - stają się świadectwem swoistej gry twórców ze schematem. A zatem dowodzą istnienia procesu dekonwencjonalizacji, nabywania świadomości trwania owej „bezmyślnej reprodukcji”, jaka dokonuje się w trakcie wytwarzania i rozpowszechniania tekstów popkulturowych. O tym, że tendencje takie są obecne w świecie masowej komunikacji, przekonują choćby przykłady pastiszów i parodii pojawiających się systematycznie w odniesieniu do najbardziej ustabilizowanych (a zatem i najbardziej schematycznych) form kultury popularnej ${ }^{5}$. I wreszcie teza trzecia, najogólniejsza i zarazem najbardziej kontrowersyjna, brzmi w sposób następujący: Popkultura w ogóle jest obszarem „przymusu powtarzania” - neurotycznej reprodukcji tekstów ufundowanych na prostym schemacie (gatunkowym, fabularnym, narracyjnym etc.). Rzecz jasna, konstatacja ta jest - w takiej postaci banałem. Przestaje jednak nim być, jeśli wyprowadzimy z niej konsekwentnie wnioski wiodące wprost ku Freudowskiej teorii „natręctwa powtarzania”, konstatując, że jako taka kultura popularna musi ostatecznie okazać się przestrzenią zinstytucjonalizowanego i nieuniknionego wytwarzania „niesamowitości” (das Unheimliche), mocą konstruowania (nie)oczekiwanych powtórzeń tego samego w pozornie innym. W tym ujęciu sama popkultura byłaby oczywiście ,niesamowita” (uncheimlich i uncanny - nie zaś amazing jak głoszą tytuły niezliczonych popularnych opowieści ${ }^{6}$ ) jako mechanizm natrętnego, niekończącego się powtarzania tych samych schematów produkcji i konsumpcji tekstów. Oczywiście przeciw tej tezie można wytoczyć natychmiast istotny i zasadny argument, orzekając, że tak rozumiane powtórzenie nie jest bynajmniej - po Freudowsku - nieoczekiwane, odbiorca tekstów popkulturowych jest bowiem doskonale świadom istniejących schematów i ich reprodukcji. Powinniśmy jednak zapytać, czy ta świadomość powtórzenia na pewno anuluje „niesamowite przeżycia” postulowane przez teorię psychoanalityczną, w myśl której niesamowitość rodzi się zawsze właśnie w konfrontacji z tym, co „swojskie i znajome” lecz „niejawne”? Czy odkrycie w dobrze znanej fabule schematu znanego skądinąd $-\mathrm{z}$ innej opowieści, która niespodziewanie okazuje się tą samą, nie budzi u odbiorcy poczucia konfuzji, zakłopotania, czy właśnie niesamowitości?

Niech będzie mi wolno zakończyć ten szkic obserwacją prywatną, czysto subiektywną, trudno jednak inaczej odwołać się do osobistego przeżycia niesamowitego w kontakcie z tekstem popkultury. Odniosę się tu do przykładu tyleż banalnego, co powszechnego i - w ten sposób - reprezentatywnego dla sposobu konsumowania tekstów kultury popularnej każdego współczesnego odbiorcy telewizji. Zarazem ilustracja ta posiada tę zaletę, że nie przywołuje w najmniejszym nawet stopniu tekstów związanych z estetyką grozy, horrorem czy fantastyką - niejako uprzywilejowanych w refleksji nad popkulturową niesamowitością (uncanny). Jeden z popularnych kanałów telewizyjnych, Comedy Central, ma w swojej „ramówce” (układzie programu) niezliczone powtórzenia kolejnych sezonów amerykańskich seriali komediowych: Friends (1994-2004) i The Big Bang Theory (2007-), wyprodukowanych odpowiednio przez NBC i CBS. Nietrudno zatem natrafić na powracające cyklicznie odcinki obu serii, co znacznie ułatwia ich konfrontację i porównanie, nawet jeśli widz nie ma takich właśnie intencji, oglądając program. Takie też było moje doświadczenie, gdy śledząc po raz kolejny perypetie

5 Pisałem o tym obszernie w artykule Przelamywanie schematu. Parodia jako zabieg dekonwencjonalizujący w literaturze popularnej, na przykładzie science fiction (Brzostek 2001).

${ }^{6}$ By wspomnieć tylko filmy The Amazing Spider-Man (2012) i, rzecz oczywista, The Amazing SpiderMan 2 (2014) wyreżyserowane przez Marca Webba. 
bohaterów, zadałem sobie niepokojące pytanie - czy oglądam jeden, wciąż ten sam serial. Oto bowiem, zgoła nieoczekiwanie, odnajduję w odcinkach The Big Bang Theory kolejne sceny, doskonale znane skądinąd (z serii Friends) i vice versa. Wystarczy kilka drobnych przykładów: pozostający w trudnych związkach miłosnych bohaterowie biorą ,szybkie śluby" w Las Vegas: Ross i Rachel (The One in Vegas), Penny i Leonard (The Matrimonial Momentum); obrażeni kochankowie w ramach okazywania sobie dowodów miłości i dawnego zaangażowania pokazują partnerom pudełeczka ze skrzętnie przechowywanymi pamiatkami (Rachel w The One With Chandler In A Box i Penny w The Romance Resonance); rezolutne dziewczęta ukrywają w swoich mieszkaniach wracających przed czasem ze służbowych wyjazdów narzeczonych i muszą borykać się ze wścibstwem przyjaciół podejrzewających zdradę (Chandler, Monica i Joey w The One With Rachel's Phone Number, Leonard, Penny i Sheldon w The Deception Verification), wreszcie w obu serialach istotną rolę odgrywa piosenka o kotku (cuchnącym lub puszystym), która okazuje się kołysanką odziedziczoną po trudnym dzieciństwie (Smelly Cat Phoebe i Soft Kitty Sheldona) etc. Nawet widz znający doskonale mechanizmy produkcji tekstów popkultury (posługiwanie się motywami obiegowymi, schematami, formułami i formatami), w momencie odbioru ${ }^{7}$ odnosi więc nieuniknione wrażenie, że ogląda sceny dobrze znane, umieszczone jednak i powracające w nieoczekiwanym kontekście, padając w ten sposób ofiarą Freudowskiego „niesamowitego przeżycia”, którego istotą jest zasada „powracania spraw podobnych” (Freud 1997: 250) sprawiająca, że „coś skądinąd niewinnego staje się niesamowite” (Freud 1997: 249).

${ }^{7}$ Trzeba w tym miejscu koniecznie podkreślić, że w teorii Freudowskiej „niesamowite przeżycia” rodzi się w sytuacjach codziennych a nie w trakcie analizy, pod wpływem sugestii psychoanalityka. 


\section{Bibliografia}

BARKER, C. (1992). Powrót z piekła (przeł. P. Kwiatkowski). Poznań: Rebis. Bloom, H. (2002). Lęk przed wptywem. Teoria poezji (przeł. A. Bielik-Robson, M. Szuster). Kraków: Universitas.

BOURDIEU, P. (2007). Szkic teorii praktyki poprzedzony trzema studiami na temat etnologii Kabylów (przeł. W. Kroker). Kęty: Wydawnictwo Marek Derewiecki.

BrzosteK, D. (2001). Przełamywanie schematu. Parodia jako zabieg dekonwencjonalizujacy $w$ literaturze popularnej, na przykładzie science fiction. „Acta Universitatis Nicolai Copernici”, Filologia Polska LVI.

BRZOsteK, D. (2005). Między Baker Street 221/B a Berggasse 19, czyli o detektywach i psychoanalitykach. W: M. Cyzman i K. Szostakowska (red.), Z filozoficznych inspiracji literatury. Torun: Interdyscyplinarne Koło Naukowe Doktorantów Uniwersytetu Mikołaja Kopernika.

BRzosteK, D. (2009). Literatura i nierozum. Antropologia fantastyki grozy, Torun: Wydawnictwo Naukowe UMK.

BRZOSTEK, D. (2013). Analiza tekstu, interpretacja zbrodni. O wartościach poznawczych fikcji detektywistycznej. W: T. Dalasiński i T. Markiewka (red.), Kryminat - gatunek poważ(a)ny? Poznań: „ProLog” Interdyscyplinarne Czasopismo Humanistyczne.

CARrol, N. (2004). Filozofia horroru albo paradoksy uczuć, przeł. M. Przylipiak, Gdańsk: Słowo/Obraz Terytoria.

CAWELTI, J. G. (1973). Koncepcja schematu w badaniach literatury popularnej (przeł. M. Dzieduszycka). „Literatura Ludowa”, nr 6, s. 44-52.

DoYle, A. C. (2007), Rytuał Musgrave'ów. W: tenże, Zagadki Sherlocka Holmesa (przeł. T. Evert). Warszawa: Oficyna Wydawnicza Rytm.

EcO, U. (1996). Struktury narracyjne u Fleminga. W: tenże, Superman w literaturze masowej. Powieść popularna - między retoryka a ideologia (przeł. J. Ugniewska). Warszawa: PIW.

Freud, S. (1997). Niesamowite. W: tenże, Pisma psychologiczne (przeł. R. Reszke). Warszawa: Wydawnictwo KR.

Freud, S. (2001). Zahamowanie, symptom i lęk. W: tenże, Histeria $i$ lęk (przeł. R. Reszke), Warszawa: Wydawnictwo KR.

KING, S. (2007). Magiel. W: tenże, Nocna zmiana (przeł. M. Wroczyński). Warszawa: Prószyński i Spółka.

LAPLANCHE, J., Pontalis, J.-B. (1996). Stownik psychoanalizy (przeł. E. Modzelewska, E. Wojciechowska). Warszawa: Wydawnictwa Szkolne i Pedagogiczne.

LASIĆ, S. (1976). Poetyka powieści kryminalnej (przeł. M. Petryńska). Warszawa: PIW. LOVECRAFT, H. P. (2012). Zew Cthulhu. W: tenże, Zgroza w Dunwich i inne przerażajace opowieści (przeł. M. Płaza). Poznań: Vesper.

MAnN, T. (1972). Czarodziejska góra (przeł. J. Kramsztyk). tom 1, Warszawa: Czytelnik.

MAnN, T. (1974). Der Zauberberg. Roman. Frankfurt am Main: S. Fischer Verlag.

NowICKA, O. (2015). Miara ofiary jest czlowiek. Antropometria $w$ wedyjskim rytuale ofiarniczym śrauta, ,Studia Religiologica”, 48 (1), s. 35-47.

SMUSZKIEWICZ, A. (1980). Stereotyp fabularny fantastyki naukowej. Wrocław: Zakład Narodowy im. Ossolińskich.

StAal, F. (1979). The Meaningless of Ritual, „Numen”, nr 26, s. 2-22.

Wróblewska, V. (2014). Od potworów do znaków pustych. Ludowe demony w polskiej literaturze dla dzieci. Torun: Wydawnictwo Naukowe UMK. 


\section{DARIUSZ BRZOSTEK}

\section{Sherlock Holmes, a Mangle And a Meaningless Ritual: The Demonic (oF) Repetitions in Popular Culture}

The article focuses on the mechanism of repeating a formula in texts of popular culture and its relations to evoking the experience of the uncanny (uncheimlich) in the process of reception of popular narratives, both those alluding to the aesthetics of horror and those following other conventions (crime fiction, comedies, etc.). The essence of this experience is the audience's discovery of (un-)expected repetitions of the same in something seemingly different, that is, an identical formula in a new, yet unknown, text. The methodological context for this analysis consists of J.G. Cawelti's concept of formula, Freud's theory of "the uncanny", Harold Bloom's concept of the anxiety of influence, and Frits Staal's notion of "the meaningless ritual". The texts analyzed herein are short stories by Stephen King, Arthur Conan Doyle, and Clive Barker as well as TV series Friends and Big Bang Theory. 